Bull. Chem. Soc. Ethiop. 2018, 32(3), 407-419.

ISSN 1011-3924

(c) 2018 Chemical Society of Ethiopia and The Authors

Printed in Ethiopia

DOI: https://dx.doi.org/10.4314/bcse.v32i3.1

\title{
CYTOTOXIC EVALUATION AND CONCURRENT ANALYSIS OF TWO DITERPENES IN THE CHLOROFORM EXTRACT OF PLECTRANTHUS BARBATUS USING A VALIDATED HPTLC-UV METHOD
}

\author{
Musarat Amina $^{1 *}$, Nawal M. Al-Musayeib ${ }^{1}$, Perwez Alam ${ }^{1}$, Fadilah S. Aleanizy ${ }^{2}$, Fulwah Y. \\ Alqahtni $^{2}$, Mansour S. Al-Said ${ }^{1}$, Nada S. Al-Rashidi ${ }^{1}$ and Faiyaz Shakeel ${ }^{2 *}$ \\ ${ }^{1}$ Department of Pharmacognosy, College of Pharmacy, King Saud University, Riyadh, Saudi \\ Arabia \\ ${ }^{2}$ Department of Pharmaceutics, College of Pharmacy, King Saud University, Riyadh, Saudi \\ Arabia
}

(Received April 22, 2018; Revised November 6, 2018; Accepted November 10, 2018)

\begin{abstract}
The objective of this study was to develop a validated high-performance thin layer chromatography (HPTLC) method for the concurrent analysis of two diterpenes Sugiol (compound 1) and 11,14dihydroxy-8,11,13-abietatrien-7-one (compound 2) in Plectranthus barbatus chloroform extract (PBCE) and to investigate cytotoxicity of both compounds. The chromatographic estimations were carried out using toluene : ethyl acetate : formic acid $(8.2: 1.3: 0.5 \mathrm{v} / \mathrm{v} / \mathrm{v})$ as mobile phase. The compact spots of biomarkers were scanned at $\lambda_{\max }=275 \mathrm{~nm}$. Cytotoxic evaluation of both compounds was performed using follicular thyroid cancer cells (FRO cells). A well resolved, compact and intense peaks of compound $1\left(R_{\mathrm{f}}=0.550 \pm 0.001\right)$ and compound $2\left(R_{\mathrm{f}}=\right.$ $0.700 \pm 0.002)$ were recorded. The proposed method for both compounds was recorded as simple, linear, precise $(\% R S D=1.02-1.25)$, accurate $(98-100 \%)$, robust and sensitive for the analysis of both compounds. Cytotoxicity evaluation showed significant cell cytotoxicity at $100 \mu \mathrm{g} / \mathrm{mL}$ concentration against the FRO cancer cells after $72 \mathrm{~h}$ of incubation. Both compounds were recorded as cytotoxic, however compound 1 showed significant cytotoxic effects. The proposed HPTLC method was found to be suitable for routine analysis of these two biomarkers in chloroform extract of $P$. barbatus. Both compounds were found to be cytotoxic against FRO cancer cells.
\end{abstract}

KEY WORDS: Diterpenes, Sugiol, Plectranthus barbatus, Cytotoxicity, HPTLC

\section{INTRODUCTION}

Plectranthus barbatus Andr. belonging to family Lamiaceae, is a perennial herb native to the India and tropical Africa, which was naturalized in the Egypt, Saudi Arabia, Pakistan, Sri Lanka, Brazilian Northeast and Southeast regions [1-3]. This plant has a long history of uses by traditional Hindu and Ayurvedic medicines as well as in the folk medicine of Brazil, tropical Africa and China with potential benefits [4]. In the literature, P. barbatus has been ascribed to possess wide range of medicinal uses which includes gastrointestinal disorders, heart diseases such as hypertension and central nervous system (CNS) disorders, respiratory disorders, genitourinary, skin affections, congestive heart failure, eczema, colic, asthma, angina and psoriasis [5, 6]. A decoction of P. barbatus leaves are used in colds, coughs, infections, aetiologies and inflammation [7]. Clinical studies on organic extracts of different parts of P. barbatus has demonstrated multiple pharmacological activities such as antimicrobial [8], hypotensive [3, 9], cytotoxic [10], anti-inflammatory [11], antioxidant [12], hepatoprotective [13], antifeedant [14], lipolysis induction in rat adipose tissue [15], total body weight reduction in rats [16], prevention of hair-loss and activation of melanogenesis process [17], antiasthmatic [18], antiaging [19] and antiallergic [20] effects. The aqueous extract of $P$. barbatus showed significant hypotensive, antispasmodic and hypoglycemic effects [21]. Also the aqueous extract of stem and leaves has been reported to enhance the intestinal transit in mice, protected against gastric lesions induced

*Corresponding author. E-mail: musarat1@rediffmail.com

This work is licensed under the Creative Commons Attribution 4.0 International License 
by ethanol or cold-restraint stress $[22,23]$ and reduced the total $\mathrm{pH}$ gastric secretion in pylorusligated rats [1]. The ethanolic root extract of $P$. barbatus exhibited potential inhibitory effects against Escherichia coli toxin-induced secretory response in Guinea pig and rabbit sileal loops [24] whereas $50 \%$ ethanolic extract showed a variety of toxic effects on different periods of pregnancy in rats [25]. However, the essential oil extracted from leaves has reported to exhibit potential antimicrobial, spasmolytic and relaxant effects $[21,25]$. Other significant uses of $P$. barbatus are as a food supplements, in Kenya and Yemen, leaves are being consumed as vegetable, as an ornamental plant or garden herb, in hedges, fences or boundary markers [26]. Phytochemical investigation of different parts of plant material revealed the presence of diterpenoids (abietane and labdane), flavonoids, phenolic compounds, tannins, phlobatannins, sapnonins, cardiac glycosides and essential oils [27-29]. Studies have shown that the leaves of $P$. barbatus growing in Brazil are rich in abietane diterpenes, whereas the roots of the Indian species contain mainly labdane diterpenes such as coleonol and forskolin, main active constituent used in number of patented pharmaceutical preparations as an over-the-counter drug for the treatment of several ailments [30].

In the recent years, high performance thin layer chromatography (HPTLC) has become one of the most widely applied analytical techniques for the estimation of chemical and biochemical markers in herbal materials. It is due to its numerous advantages which include simplicity, low operating cost and good resolution of active constituents with reasonable accuracy in short time, possibility of multiple sample detection, high sample throughput and rapidly obtained results [31]. The major advantage of HPTLC is that parallel analysis of multiple samples using a small amount of mobile phase, unlike HPLC, thus reducing the analysis time and cost of analysis [32]. HPTLC chromatogram pattern comparison seems to be promising for fingerprinting the active compounds in plant extract. A little information is available regarding analytical methods for the qualitative and/or quantitative estimation of sugiol (12-hydroxyabieta-8(14), 9(11),12-trien-7one) and 11,14-dihydroxy-8,11,13-abietatrien-7-one (Figure 1). These two abietane diterpene occur naturally in many plant species and are reported to possess significant biological activities $[33,34]$. Studies have shown that sugiol exhibit anti-inflammatory, anti-tumor, antimicrobial and aldose reductase inhibitory activities [33-36].

Consideration the importance of HPTLC and the need for chemical standardization of herbal extracts on the basis of isolated chemical entities, especially bioactive ones for global acceptances, it was decided to carry out the chemical profiling of chloroform extract of $P$. barbatus on the basis of two bioactive diterpenes. In the present study, we herein report on cytotoxic activity of chloroform extract as well as the pure chemical constituents isolated from $P$. barbatus, followed by the development of a sensitive selective hyphenated HPTLC method for the quantization of sugiol and11,14-dihydroxy-8,11,13-abietatrien-7-one in the extract.

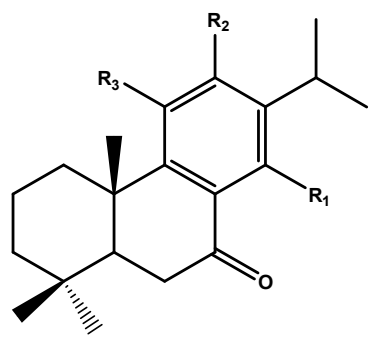

Sugiol ( $\left.\mathbf{R}_{1}=\mathbf{R}_{3}=\mathbf{H}, \mathbf{R}_{2}=\mathbf{O H}\right) \mathbf{1}$

11, 14-dihydroxy-8, 11, 13-abietatrien-7-one

$\left(\mathbf{R}_{1}=\mathbf{R}_{3}=\mathrm{OH}, \mathbf{R}_{2}=\mathbf{H}\right) 2$

Figure 1. Molecular structure of sugiol and 11,14-dihydroxy-8,11,13-abietatrien-7-one.

Bull. Chem. Soc. Ethiop. 2018, 32(3) 


\section{EXPERIMENTAL}

\section{Plant material}

The aerial parts of $P$. barbatus Andrews (Lamiaceae) were collected from Makkah roadside, AlTaif, Al-Hada region of Saudi Arabia in March 2014. The plant was taxonomically identified and authenticated by Dr. Muhammed Yousef, Department of Pharmacognosy, College of Pharmacy, King Saud University, Riyadh, Saudi Arabia. A voucher specimen (15732) has been deposited in the herbarium of the Department.

\section{Chemicals and reagents}

High purity grades of methanol, ethanol and n-hexane were procured from E-Merck (Darmstadt, Germany). High purity grades of chloroform and n-butanol were procured from Sigma Aldrich (St. Louis, MO, USA). AR grade toluene, ethyl acetate and formic acid were obtained from BDH Laboratory Supplies (Poole, UK). FRO thyroid cancer cell line was kindly gifted from King Faisal Specialist Hospital and Research Centre, Riyadh, Saudi Arabia.

\section{Extraction of plant material}

The air-dried powdered aerial parts of P. barbatus $(2000 \mathrm{~g})$ was soaked in $70 \%$ ethanol for seven days at room temperature, extracted three times in the same solvent and filtered. The combined filtrate was concentrated under reduced pressure at $50 \pm 5{ }^{\circ} \mathrm{C}$, residue $(220.2 \mathrm{~g})$ obtained was dissolved in a mixture of methanol and water $(9: 1)$ and the resulting solution was partitioned successively with n-hexane, chloroform $\left(\mathrm{CHCl}_{3}\right)$, ethyl acetate (EtOAc) and nbutanol (n-BuOH) to obtain n-hexane (25.5), $\mathrm{CHCl}_{3}$ (130.6), EtOAc (30.3 g) and n-BuOH (10.9 g) fractions, respectively. The $\mathrm{CHCl}_{3}$ soluble fraction $(120 \mathrm{~g})$ rich in quantity and chemical constituents was subjected to gravity column chromatography. It was dissolved in minimum amount of methanol, uniformly adsorbed over $200 \mathrm{~g}$ of silica gel (230-400 mesh) and freed from solvent to obtain free flowing material. A glass column was packed with $500 \mathrm{~g}$ of $\mathrm{SiO}_{2}$ gel (230400 mesh) in n-hexane- $\mathrm{CHCl}_{3}$ and successively eluted with hexane- $\mathrm{CHCl}_{3}$ (9:1), hexane$\mathrm{CHCl}_{3}(8: 2)$, hexane- $\mathrm{CHCl}_{3}(7: 3)$, hexane- $\mathrm{CHCl}_{3}(6: 4), \mathrm{CHCl}_{3}$ and then $\mathrm{MeOH}$. The combined 10 and $20 \% \mathrm{CHCl}_{3}$ in n-hexane fractions $(23.0 \mathrm{~g})$ was re-chromatographed over $\mathrm{SiO}_{2}(230-400$ mesh (E-Merck, Darmstadt, Germany) using hexane- $\mathrm{CHCl}_{3}$ mixtures of increasing polarity. A total of 220 fractions $(150 \mathrm{~mL}$ each) were collected. Fractions $25-45$ obtained from hexane$\mathrm{CHCl}_{3}$ (9:1) were pooled on the basis of similar TLC pattern using $\mathrm{CHCl}_{3}: \mathrm{MeOH}(98: 2)$ as a developing solvent and spots were visualized by spraying plate with $p$-anisaldehyde: $\mathrm{H}_{2} \mathrm{SO}_{4}(0.5$ $\mathrm{mL}$-anisaldehyde in $50 \mathrm{~mL}$ glacial acetic acid and $1 \mathrm{~mL} 97 \% \mathrm{H}_{2} \mathrm{SO}_{4}$ ) followed by heating over hot plate for $5 \mathrm{~min}$ at $110{ }^{\circ} \mathrm{C}$. Sugiol $(23.2 \mathrm{mg})$ was crystallized from $\mathrm{MeOH}$ as colorless crystals (m.p. $283-284{ }^{\circ} \mathrm{C} ; \mathrm{C}_{20} \mathrm{H}_{28} \mathrm{O}_{2}$. ESIMS: $\mathrm{m} / \mathrm{z}=323[\mathrm{M}+\mathrm{Na}]^{+}, \mathrm{m} / \mathrm{z}=301[\mathrm{M}+\mathrm{H}]^{+},{ }^{1} \mathrm{H}$ and ${ }^{13} \mathrm{C}$-NMR) [37]. Similarly, fractions eluted in $30 \%$ chloroform in hexane resulted in the isolation of another abietane diterpene, identified as 11,14-dihydroxy-8,11,13-abietatrien-7-one, crystallized in $\mathrm{MeOH}$ as yellow needles (m.p. 178-180 ${ }^{\circ} \mathrm{C} ; \mathrm{C}_{20} \mathrm{H}_{28} \mathrm{O}_{3}$. ESIMS: $\mathrm{m} / \mathrm{z}=339$ $[\mathrm{M}+\mathrm{Na}]{ }^{+},{ }^{1} \mathrm{H}$ and $\left.{ }^{13} \mathrm{C}-\mathrm{NMR}\right)$ [38]. The structures of both the compounds were confirmed by comparisons of physical constants and spectral data of with previously reported values in literature $[37,38]$.

\section{Apparatus and reagents}

The two cytotoxic diterpene biomarkers sugiol (1) and 11,14-dihydroxy-8,11,13-abietatrien-7one (2) were isolated as pure compound from $P$. barbatus. In addition, the AR grade toluene, ethyl acetate and formic acid were purchased from BDH (Poole, UK). The glass-backed silica 
gel $60 \mathrm{~F}_{254}$ plates for the HPTLC analysis were purchased from E-Merck (Darmstadt, Germany). Furthermore, biomarkers compound $\mathbf{1}$ and $\mathbf{2}$ along with extract (PBCE) were applied band wise to the chromatographic plates using CAMAG Automatic TLC Sampler-4 (Switzerland) and the plates were development in automatic development chamber (ADC2) (Switzerland). The developed HPTLC plates were then scanned and documented by CATS 4 (CAMAG) and TLC Reprostar 3 (CAMAG), respectively.

\section{HPTLC instrumentation and conditions}

The HPTLC analysis of compounds 1 and 2 in PBCE was carried out on $10 \times 10 \mathrm{~cm}$ HPTLC plates, where the band size of each track was $6 \mathrm{~mm}$ wide and $7.0 \mathrm{~mm}$ apart. Both the markers as well as the extract were applied on HPTLC plate at a rate of $160 \mathrm{~nL} / \mathrm{s}$ using microlitre syringe fitted with the automatic TLC Sampler-4. The plates were developed in a pre-saturated twintrough glass chamber $(20 \times 10 \mathrm{~cm})$ under the chamber saturation condition (at $25 \pm 2^{\circ} \mathrm{C}$ and under $60 \pm 5 \%$ humidity). Further, the developed HPTLC plates were dried to furnish compact spots of the biomarkers as well as the different phytoconstituents present in the extract. The mixture of toluene: ethyl acetate: formic acid $(8.2: 1.3: 0.5 \mathrm{v} / \mathrm{v} / \mathrm{v})$ was used as a mobile phase. The dried plate was quantitatively analyzed at $\lambda_{\max }=275 \mathrm{~nm}$ wavelength in absorbance mode.

\section{Preparation of standard stock solutions}

The stock solutions of compound $\mathbf{1}$ and $\mathbf{2}(1 \mathrm{mg} / \mathrm{mL})$ were prepared in chloroform, following further dilution with chloroform to provide seven different concentrations ranging from 10 to $120 \mu \mathrm{g} / \mathrm{mL}$. $10 \mu \mathrm{L}$ of each dilution of both biomarkers were applied on the HPTLC plate through the microliter syringe attached with the applicator to provide the linearity range of 100$1200 \mathrm{ng} / \mathrm{band}$.

\section{Validation of method}

The proposed HPTLC method was validated for the determination of limit of detection (LOD), limit of quantification (LOQ), linearity range, precision, recovery as accuracy and robustness according to International Conference on Harmonization (ICH) guidelines [39]. ICH guidelines are generally used for validation of such studies [39-42]. The detail procedure about determination of validation parameters is presented in our previous publications [43, 44].

\section{Cytotoxic evaluation}

Undifferentiated/anaplastic thyroid cancer cell line (FRO) was kindly gifted from King Faisal Specialist Hospital and Research Centre, Riyadh, Saudi Arabia. The cells were cultured in humidified air with $5 \% \mathrm{CO}_{2}$ at $37{ }^{\circ} \mathrm{C}$ in RPMI-1640 medium with L-glutamine and sodium bicarbonate (R8758, Sigma Aldrich, St. Louis, MO, USA) and supplemented with $10 \%$ fetal bovine serum (FBS) and 1\% penicillin-streptomycin both from (Gibco).

The cancer cell lines were maintained in RPMI-1640 that included L-glutamine (GIBCO) with $10 \%$ FBS (GIBCO) and $1 \%$ penicillin-streptomycin (GIBCO). Cells were cultured at $37{ }^{\circ} \mathrm{C}$ in a $5 \% \mathrm{CO}_{2}$ incubator $[45,46]$. The effect of chloroform extract of plant (PBCE) along with pure isolated compounds $\mathbf{1}$ and $\mathbf{2}$ were evaluated on cellular viability using Alamar Blue assay (BUF012B; AbDSerotec, Langford Ln, Kidlington OX5 1GE, UK). The Alamar Blue assay is used to assess cell viability based on the reduction potential of metabolically active cells. Viable cells were seeded in the growth medium into 96-well microtiter plates $\left(1 \times 10^{4}\right.$ cells/well $)$ and were incubated at $37{ }^{\circ} \mathrm{C}$ in a $5 \% \mathrm{CO}_{2}$ incubator for $24 \mathrm{~h}$. The extract (PBCE), compounds 1 and 2 were adjusted to final 30,50 and $100 \mu \mathrm{g} / \mathrm{mL}$ concentrations by diluting with the growth medium. After standing for $24 \mathrm{~h}$, media were removed and the test sample was added to each 
well. Control wells consisted of cells alone. After 24,48 and $72 \mathrm{~h}$ of addition of test sample, 10 $\mu \mathrm{L}$ of Alamar Blue reagent was added to the each well (final concentration, $10 \mu \mathrm{g} / \mathrm{mL}$ ) and the plates were incubated at $37{ }^{\circ} \mathrm{C}$ for $4 \mathrm{~h}$. After incubation, plates were read using a spectrophotometric microplate reader (Biotek Synergy 2; Biotek Instruments, Highland Park, Winooski, Vermont, NE, USA) and the relative fluorescence unit was recorded. Cell viability was calculated using Eq. (1):

$\%$ Cell viability $=\frac{\text { Flourescence of treated cells }}{\text { Flourescence of untreated (control) cells }} \times 100$

Results were expressed as percentage cell viability versus the control.

\section{Statistical analysis}

The statistical analysis was carried out by one-way analysis of variance (ANOVA) followed by Dunnet's test for the estimation of total variation in a set of data. Results were expressed as mean \pm SD. $p<0.01$ was considered significant.

\section{RESULTS AND DISCUSSION}

HPTLC method development and validation

The mobile phase selection for the HPTLC analysis was carried out by testing various compositions of different solvents. Of these, the combination of toluene: ethyl acetate: formic acid $(8.2: 1.3: 0.5 \mathrm{v} / \mathrm{v} / \mathrm{v})$ was found to be the best mobile phase for the development and quantitative analysis of compound $\mathbf{1}$ and 2 . An intense, sharp and compact peak of compounds $\mathbf{1}$ and 2 were found at $R_{\mathrm{f}}=0.550 \pm 0.001$ and $0.700 \pm 0.002$, respectively (Figure 2).

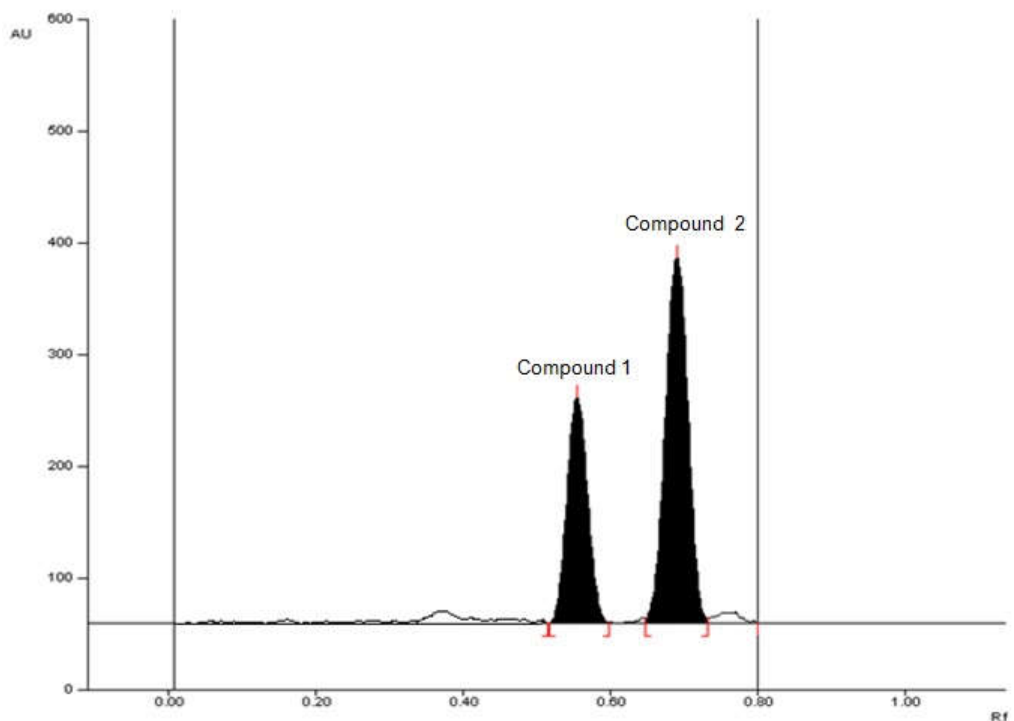

Figure 2. Chromatogram of compound $1\left(\mathrm{R}_{\mathrm{f}}=0.550 \pm 0.001\right)$ and compound $2\left(\mathrm{R}_{\mathrm{f}}=0.700 \pm\right.$ $0.002)$ at $\lambda_{\max }=275 \mathrm{~nm}$; mobile phase: toluene: ethyl acetate: formic acid (8.2:1.3:0.5 $\mathrm{v} / \mathrm{v} / \mathrm{v})$. 
This method clearly separated the biomarkers compound $\mathbf{1}$ and $\mathbf{2}$ as well as different constituents of PBCE (Figure 3A and B).

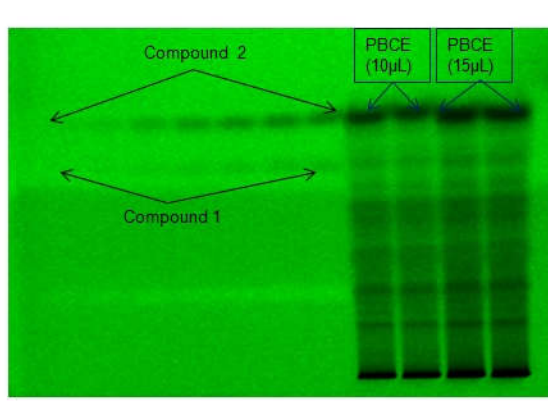

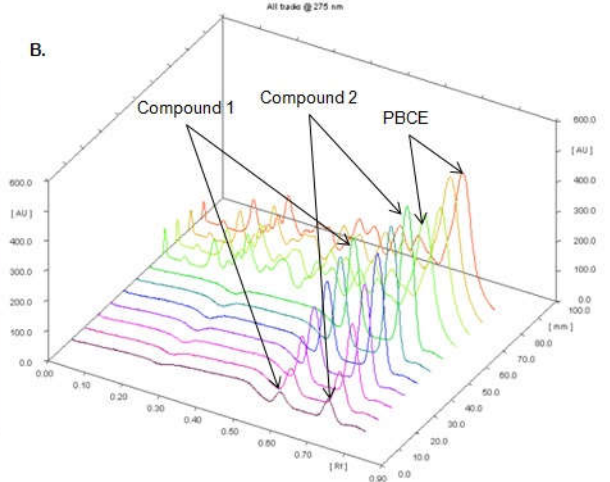

Figure 3. Quantification of compound $\mathbf{1}$ and compound $\mathbf{2}$ in the chloroform extract of $P$. barbatus (PBCE) by HPTLC; (A) pictogram of HPTLC plate at short UV $(\lambda=254$ $\mathrm{nm}$ ) and (B) 3-D display of all tracks at $\lambda=275 \mathrm{~nm}$.

The mobile phase volume and optimized saturation time for the saturation of developing chamber were found to be $20 \mathrm{~mL}$ and $20 \mathrm{~min}$, respectively. The identities of the bands of the extracts were confirmed by overlaying their spectra along with the spectra of compound $\mathbf{1}$ and $\mathbf{2}$ (Figure 4).

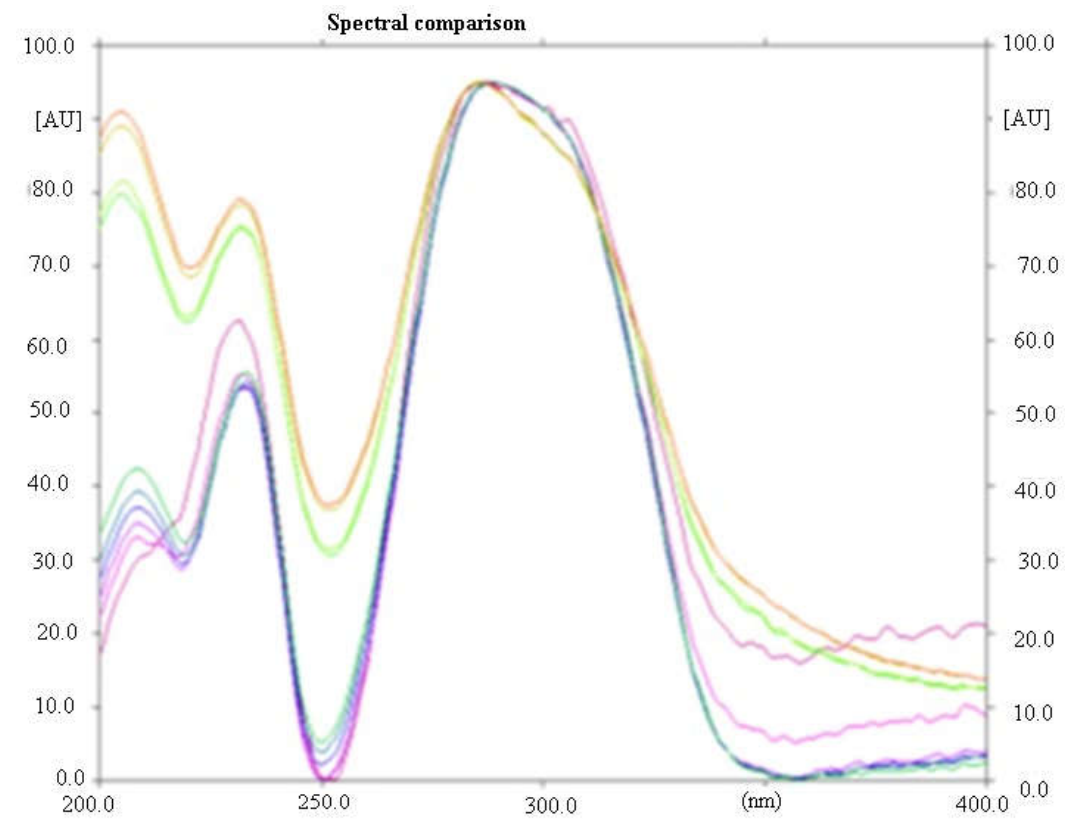

Figure 4. Spectral comparisons of different tracks at $275 \mathrm{~nm}$ (different color codes represent different concentrations of compounds).

Bull. Chem. Soc. Ethiop. 2018, 32(3) 
The developed method was found to be quite selective with high baseline resolution. The regression equation/correlation co-efficient $\left(r^{2}\right)$ for compounds $\mathbf{1}$ and $\mathbf{2}$ were found as $y=6.32 x$ $+552 / 0.996 \pm 0.0004$ and $y=11.1 x+760 / 0.998 \pm 0.0002$, respectively, in the linearity range of 100-1200 ng/spot while the LOD/LOQ for compounds 1 and 2 were found as 9.96/30.1 ng/band and $13.1 / 39.7 \mathrm{ng} / \mathrm{band}$, respectively. The recoveries as accuracy study for the proposed method was recorded (Table 1). The \% recovery/RSD (\%) for compounds 1 and $\mathbf{2}$ were found to be 98.4-100/1.18-1.63 and 98.0-99.5/1.51-2.15, respectively. \% RSD for intra-day/inter-day precisions $(\mathrm{n}=6)$ of compounds 1 and 2 were recorded as 1.07-1.19/1.02-1.15 and 1.06$1.25 / 1.04-1.22$, respectively, which exhibits the good precision of the proposed method. The robustness of proposed method was checked by making a small deliberate change in the mobile phase composition, saturation time and mobile phase volume and the obtained data are reported in the Table 3. The low values of \% RSD indicated that the proposed method was robust.

Table 1. Recovery as accuracy studies of the proposed HPTLC method $(n=6)$. Comp. 1: Compound $\mathbf{1}$; Comp. 2: Compound 2

\begin{tabular}{|c|c|c|c|c|c|}
\hline \multirow{2}{*}{$\begin{array}{c}\text { Percent (\%) of } \\
\text { Comp. 1 and Comp. 2 } \\
\text { added to analyte }\end{array}$} & Theoretical concentration & \multicolumn{2}{|c|}{$\begin{array}{c}\text { Concentration found } \\
\text { of Comp. 1 and Comp. }\end{array}$} & \multicolumn{3}{|c|}{ \% Recovery } \\
\cline { 3 - 6 } & $\mathbf{2}$ (ng/mL) & Comp. 1 & Comp. 2 & Comp. 1 & Comp. 2 \\
\hline 0 & 200 & $197 \pm 3.21$ & $196 \pm 4.21$ & 98.4 & 98.0 \\
\hline 50 & 300 & $301 \pm 4.26$ & $299 \pm 5.51$ & 100 & 99.5 \\
\hline 100 & 400 & $395 \pm 4.86$ & $395 \pm 6.71$ & 98.7 & 98.8 \\
\hline 150 & 500 & $498 \pm 5.91$ & $496 \pm 7.49$ & 99.6 & 99.1 \\
\hline
\end{tabular}

Table 2. Precision of the proposed HPTLC method $(n=6)$.

\begin{tabular}{|c|c|c|c|c|}
\hline \multirow{2}{*}{$\begin{array}{c}\text { Conc. } \\
\text { (ng/spot) }\end{array}$} & \multicolumn{2}{|c|}{ Compound 1 } & \multicolumn{2}{c|}{ Compound 2 } \\
\cline { 2 - 5 } & Intra-day precision & Inter-day precision & Intra-day precision & Inter-day precision \\
\cline { 2 - 5 } & $\begin{array}{c}\text { Mean conc. } \\
\text { found } \pm \mathrm{SD}\end{array}$ & $\begin{array}{c}\text { Mean conc. } \\
\text { found } \pm \mathrm{SD}\end{array}$ & $\begin{array}{c}\text { Mean conc. } \\
\text { found } \pm \mathrm{SD}\end{array}$ & $\begin{array}{c}\text { Mean conc. } \\
\text { found } \pm \mathrm{SD}\end{array}$ \\
\hline 400 & $395 \pm 4.24$ & $392 \pm 4.01$ & $397 \pm 4.25$ & $395 \pm 4.14$ \\
\hline 600 & $601 \pm 6.87$ & $596 \pm 6.59$ & $597 \pm 6.82$ & $595 \pm 6.69$ \\
\hline 800 & $797 \pm 9.51$ & $792 \pm 9.13$ & $797 \pm 9.98$ & $795 \pm 9.73$ \\
\hline
\end{tabular}

Table 3. Robustness of the proposed HPTLC method $(n=6)$.

\begin{tabular}{|l|c|c|}
\hline \multirow{2}{*}{ Optimization condition } & Compound 1 (400 ng/band) & Compound 2 (400 ng/band) \\
\cline { 2 - 3 } & SD & SD \\
\hline $\begin{array}{l}\text { Mobile phase composition; } \\
\text { (toluene: ethyl acetate: formic acid) }\end{array}$ & & \\
\hline$(8.2: 1.3: 0.5)$ & 4.59 & 4.62 \\
\hline$(7: 2.3: 0.7)$ & 4.63 & 4.52 \\
\hline$(6.4: 3.2: 0.4)$ & 4.69 & 4.58 \\
\hline Mobile phase volume (for saturation) & & \\
\hline$(18 \mathrm{~mL})$ & 4.38 & 4.52 \\
\hline$(20 \mathrm{~mL})$ & 4.35 & 4.55 \\
\hline$(22 \mathrm{~mL})$ & 4.31 & 4.57 \\
\hline Duration of saturation & & \\
\hline$(10 \mathrm{~min})$ & 4.55 & 4.51 \\
\hline$(20 \mathrm{~min})$ & 4.51 & 4.53 \\
\hline$(30 \mathrm{~min})$ & 4.59 & 4.56 \\
\hline
\end{tabular}


The intra-day and inter-day precision for the proposed method is recorded in Table 2 and the HPTLC is an advanced form of instrumental TLC which has various advantages in comparison to other techniques like HPLC and other chromatographic methods in the analysis of different markers. By using HPTLC method, many samples can be separated on the same HPTLC plate simultaneously which resulted in high through-put and lowered operating cost. The compounds having different light absorption capacity or colors can also be identified using different mode of evaluation by HPTLC. The plates used in the HPTLC analysis are disposable hence it does not require regeneration or essential clean-up. The availability of many stationary phases has expanded the HPTLC application to various kinds of samples contrary with the separation on bare silica gel. The HPTLC technique is applied in qualitative and quantitative separations of compounds in mixtures, where the quantitative mode operates in a more optimized way (standardized with a given procedure) and hence applicable in the assay of compounds in samples [47-49].

\section{HPTLC analysis of compound 1 and compound 2}

The developed HPTLC method was used for the concurrent analysis of compounds $\mathbf{1}$ and $\mathbf{2}$ in the extracts PBCE (Figure 5). By applying the above developed method, the quantity of compound 1 and 2 in PBCE were found as 2.04 and $15.9 \mu \mathrm{g} / \mathrm{mg}$, respectively, of the dried weight of extracts. This is a maiden report which demonstrated the development of an economical, precise, accurate and simple HPTLC method for the concurrent analysis of cytotoxic biomarkers sugiol (1) and 11,14-dihydroxy-8,11,13-abietatrien-7-one (2) in the chloroform extract of $P$. barbatus (PBCE).

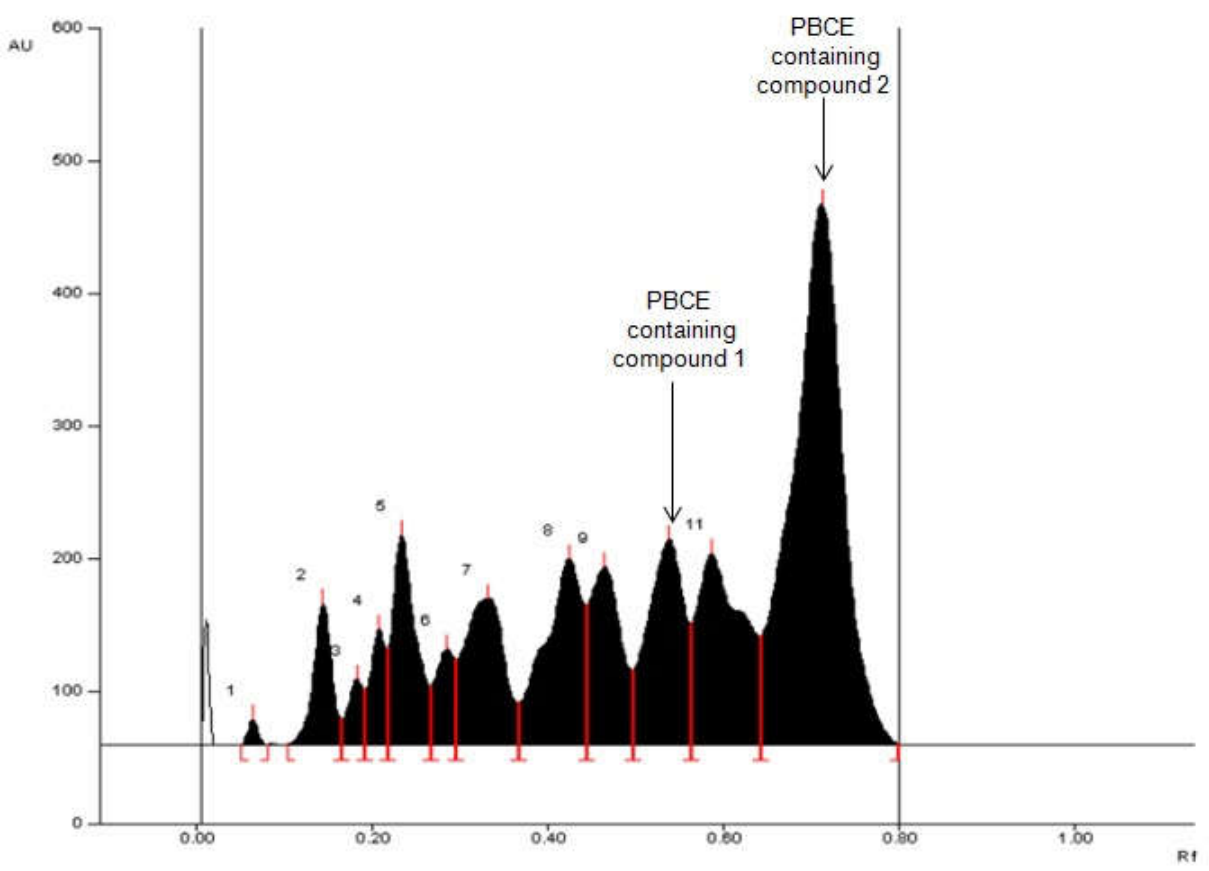

Figure 5. Chromatogram of chloroform extract of $\mathrm{P}$. barbatus (PBCE) at $\lambda=275 \mathrm{~nm}$; [compound 1, spot 10, $\mathrm{R}_{\mathrm{f}}=0.55$; compound 2, spot 12, $\left.\mathrm{R}_{\mathrm{f}}=0.70\right)$ ].

Bull. Chem. Soc. Ethiop. 2018, 32(3) 
Cytotoxic evaluation

Cytotoxicity of chloroform extract of $P$. barbatus along with sugiol (1) and 11,14-dihydroxy-8, 11,13-abietatrien-7-one (2) were evaluated using Alamar Blue assay. The Alamar Blue assay was used to assess cell viability and cell proliferation and is based on the reduction potential of metabolically active cells. The effect of chloroform extract of $P$. barbatus (PBCE), compound 1 and 2 on FRO cells viability at different concentrations $(30,50$ and $100 \mu \mathrm{g} / \mathrm{mL})$ at different time intervals $(24,48$ and $72 \mathrm{~h})$ is demonstrated in Figure $6 \mathrm{~A}, \mathrm{~B}$ and C. As shown in Figure 6A-C, there was no significant alteration in cells viability at $30 \mu \mathrm{g} / \mathrm{mL}$ concentration of extract while some reduction in the viability of FRO cells was observed at $50 \mu \mathrm{g} / \mathrm{mL}$ and $100 \mu \mathrm{g} / \mathrm{mL}$ concentration of the extract after incubation of cells for 48 (Figure 6B) and $72 \mathrm{~h}$ (Figure 6C) periods, respectively. At $100 \mu \mathrm{g} / \mathrm{mL}$ concentration of extract, cells viability reduction was the most for extract after 24, 48 and $72 \mathrm{~h}$, respectively (Figure 6A-C). However significant cell cytotoxicity was observed with compound 1 at concentration of $30 \mu \mathrm{g} / \mathrm{mL}$ at 24,48 , and $72 \mathrm{~h}$ (Figure. 6A-C). However, no signs of cytotoxicity were observed for compound 2 at $30 \mu \mathrm{g} / \mathrm{mL}$ concentration. Meanwhile at $50 \mu \mathrm{g} / \mathrm{mL}$ concentration, compound 2 showed around $40 \%$ reduction in cell viability and even more cytotoxicity was observed for compound $\mathbf{2}$ at higher concentrations $(100 \mu \mathrm{g} / \mathrm{mL})$ as represented in Figure 6A-C. Thus our results clearly show that compound 1 was the most cytotoxic among others.
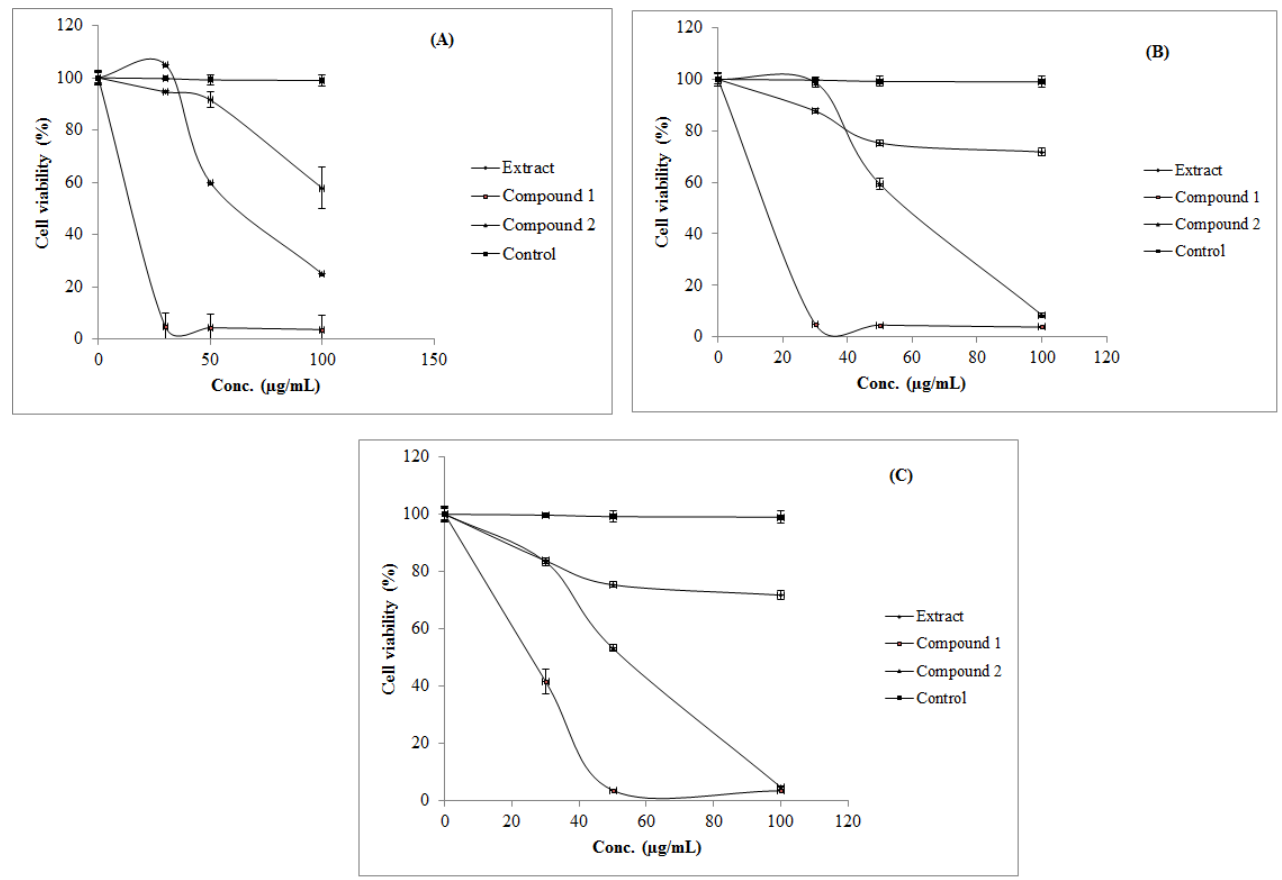

Figure 6. Cell viability (\%) of FRO cells after incubation with extract, compound $\mathbf{1}$ and $\mathbf{2}$ in a dose dependent manner; cell viability of FRO cells with extract, compound 1, and compound 2 along with control at 30, 50 and $100 \mu \mathrm{g} / \mathrm{mL}$ concentrations after (A) $24 \mathrm{~h}$, (B) $48 \mathrm{~h}$ and (C) $72 \mathrm{~h}$ incubation assessed using Alamar Blue assay. Results are expressed as \% mitochondrial activity for the Alamar Blue assay. Results are presented as mean $\pm \mathrm{SD}, \mathrm{n}=3$.

Bull. Chem. Soc. Ethiop. 2018, 32(3) 
The results of cytotoxicity evaluation in terms of maximum inhibition (MI) and $\mathrm{IC}_{50}$ are furnished in Table 4 [46]. The values of $\mathrm{IC}_{50}$ and MI for extract, compound $\mathbf{1}$ and compound $\mathbf{2}$ were determined by concentration-dependent cell viability curves shown in Figure 6A-C. The MI value for extract was recorded as $42.2 \pm 8.00,28.2 \pm 1.50$ and $28.2 \pm 7.86$ after 24,48 and $72 \mathrm{~h}$, respectively. However, the MI value for compound 1 was recorded as $96.3 \pm 5.60,96.2 \pm$ 1.04 and $96.5 \pm 1.88 \%$ after 24,48 and $72 \mathrm{~h}$, respectively, which were significant in comparison with extract $(p<0.05)$. On the other hand, the MI value for compound 2 was recorded as $75.0 \pm$ $1.08,91.5 \pm 1.64$ and $95.2 \pm 2.02 \%$ after 24,48 and $72 \mathrm{~h}$, respectively, which were also significant in comparison with extract $(p<0.05)$. Overall, compound 1 was found to be more efficacious than extract and compound 2 against FRO cells. Control sample indicated cell growth at negligible extent (Figure 6). The $\mathrm{IC}_{50}$ value of extract was obtained as 128, 165 and $166 \mu \mathrm{g} / \mathrm{mL}$ after 24,48 and $72 \mathrm{~h}$, respectively. However, the $\mathrm{IC}_{50}$ value for compound 1 was recorded as $18.4,18.5$ and $31.2 \mu \mathrm{g} / \mathrm{mL}$ after 24,48 and $72 \mathrm{~h}$, respectively. On the other hand, the $\mathrm{IC}_{50}$ value for compound 2 was recorded as $72.1,61.9$ and $55.5 \mu \mathrm{g} / \mathrm{mL}$ after 24,48 and $72 \mathrm{~h}$, respectively. The $\mathrm{IC}_{50}$ value of compound $\mathbf{1}$ was significantly lower than extract and compound 2 .

Table 4. $\mathrm{IC}_{50}$ and MI values of extract, compound 1, compound $\mathbf{2}$ and control on FRO cells after 24, 48 and $72 \mathrm{~h}$ of treatment (Mean $\pm \mathrm{SD}, \mathrm{n}=3$ ).

\begin{tabular}{|l|c|c|c|c|c|c|}
\hline \multirow{2}{*}{$\begin{array}{l}\text { Sample } \\
\text { matrices }\end{array}$} & \multicolumn{3}{|c|}{$\mathrm{IC}_{50}(\mu \mathrm{g} / \mathrm{mL}) \pm \mathrm{SD}$} & \multicolumn{3}{c|}{$\mathrm{MI}(\%) \pm \mathrm{SD}$} \\
\cline { 2 - 7 } & $24 \mathrm{~h}$ & $48 \mathrm{~h}$ & $72 \mathrm{~h}$ & $24 \mathrm{~h}$ & $48 \mathrm{~h}$ & $72 \mathrm{~h}$ \\
\hline Extract & $128 \pm 6.45$ & $165 \pm 4.27$ & $166 \pm 5.91$ & $42.2 \pm 8.00$ & $28.2 \pm 1.50$ & $28.2 \pm 7.86$ \\
\hline Compound 1 & $18.4 \pm 0.92$ & $18.5 \pm 0.83$ & $31.2 \pm 1.57$ & $96.3 \pm 5.60$ & $96.2 \pm 1.04$ & $96.5 \pm 1.88$ \\
\hline Compound 2 & $72.1 \pm 2.58$ & $61.9 \pm 2.22$ & $55.5 \pm 2.36$ & $75.0 \pm 1.08$ & $91.5 \pm 1.64$ & $95.2 \pm 2.02$ \\
\hline Control & - & - & - & $1.00 \pm 0.20$ & $1.00 \pm 0.20$ & $1.00 \pm 0.20$ \\
\hline
\end{tabular}

Standard deviation (SD); the percent of maximum inhibition ( $\% \mathrm{MI})$; the concentration responsible for $50 \%$ of cell inhibition $\left(\mathrm{IC}_{50}\right)$.

The cytotoxicity activity evaluation of the chloroform extract of the plant $(100 \mu \mathrm{g} / \mathrm{mL}$ at 72 h) showed enough reduction in the viability of undifferentiated FRO cells. The two abietanetype diterpenes viz., 12-hydroxyabieta-8(14),9(11),12-trien-7-one (1) and 11,14-dihydroxy8,11,13-abietatrien-7-one (2) were found to be cytotoxic. However, compound $\mathbf{1}$ showed significant cytotoxic effects at different time intervals.

Cytotoxicity studies suggested that compound $\mathbf{1}$ was around four fold more efficacious in comparison with extract after 24 and 48 h of incubation period. Overall, compound 1 was found to be more potent than extract and compound $\mathbf{2}$. Therefore, compound $\mathbf{1}$ could be formulated in different dosage forms for the chemoprevention of cancers in future studies.

\section{CONCLUSION}

The maiden HPTLC method developed for the concurrent analysis of cytotoxic biomarkers sugiol and 11,14-dihydroxy-8,11,13-abietatrien-7-one in the $P$. barbatus extract may be further employed in the analysis of these biomarkers in extracts of other species of same genus as well as different genus to establish the chemotaxonomic relationship. The above developed method can also be used in the quantitative analysis of these two cytotoxic biomarker in marketed preparations, quality control of herbal drugs containing these two biomarkers and study of their degradation kinetics. Cytotoxicity evaluation indicated that compound 1 was more efficacious in comparison with extract. Overall, compound 1 was found to be more potent than extract and compound 2. Hence, compound $\mathbf{1}$ could be formulated in different dosage forms for the chemoprevention of cancers in future studies. 


\section{ACKNOWLEDGEMENT}

This research was supported by a grant from the Research Center of the Center for Female Scientific and Medical Colleges, Deanship of Scientific Research, King Saud University.

\section{REFERENCES}

1. Schultz, C.; Bossolani, M.P.; Torres, L.M.B.; Lima-Landman, M.P.; Lapa, A.J.; Souccar, C. Inhibition of the gastric $\mathrm{H}^{+}, \mathrm{K}^{+}$-ATPase by plectrinone $\mathrm{A}$, a diterpenoid isolated from Plectranthus barbatus Andrews. J. Ethnopharmacol. 2007, 111, 1-7.

2. Jin, Q.D.; He, B.H. Minor constituents from Coleus forskohlii. Acta Bot. Yunn. 1998, 20, 469-473.

3. de Souza, N.J.; Dohadwalla, A.N.; Reden, J. Forskolin: a labdane diterpenoid with antihypertensive, positive inotropic, platelet aggregation inhibitory, and adenylatecyclase activating properties. Med. Res. Rev. 1983, 3, 201-219.

4. Lukhoba, C.W.; Simmonds, M.S.J.; Paton, A.J. Plectranthus: A review of ethnobotanical uses. J. Ethnopharmacol. 2006, 103, 1-24.

5. Monograph Coleus forskohlii. Alt. Med. Rev. 2006, 11, 47-51.

6. Alasbahi, R.H.; Melzig, M.F. Plectranthus barbatus: A review of phytochemistry, ethnobotanical uses and pharmacology-part 1. Planta Med. 2010, 76, 653-661.

7. Lorenzi, H.; Matos, F.J.A. Plectranthus barbatus Andrews in Plantas Medicinais no Brasil: Nativas e Exoticas Cultivadas. SP: Institute Plantarum, Nova Odessa, Lorenzi, H.; Matos, F.J.A. (Eds.), 2000, pp. 259-260.

8. Runyoro, D.K.B.; Matee, M.I.N.; Ngassapa, O.D.; Joseph, C.C.; Mbwambo, Z.H. Screening of Tanzanian medicinal plants for anti-Candida activity. BMC Compl. Alt. Med. 2006, 6, E11.

9. Kelecom, A. Isolation, structure determination, and absolute configuration of barbatusol, a new bioactive diterpene with a rearranged abietane skeleton from the labiate Coleus barbatus. Tetrahedron 1983, 39, 3603-3608.

10. Costa, M.C.C.D.; Nascimento, S.C. Actividadecitotóxica de Plectranthus barbatus Andr. (Lamiaceae). Acta Farm. Bonaer. 2003, 22, 155-158.

11. Matu, E.N.; van Staden, J. Antibacterial and anti-inflammatory activities of some plants used for medicinal purposes in Kenya. J. Ethnopharmacol. 2003, 87, 35-41.

12. Tamasiro, V.; Davino, S.C.; Freitas, P.C.D.; Deodato, P.C.; Barros, de Maroes, S.B. In vitro antioxidant activity of Coleus barbatus (Andr.) Benth (false boldo) and Peumusboldo (Molina) (Boldo do Chile): A comparative study. Rev. Farm. Bioquim. Uni. Sao Paulo 1998, 34, 15-17.

13. Staudinger, J.L.; Ding, X.; Lichti, K. Pregnane X receptor and natural products: Beyond drug-drug interactions. Expert Opin. Drug Met. Toxicol. 2006, 2, 847-857.

14. Kubo, I.; Matsumoto, T.; Tori, M.; Asakawa, Y. Structure of plectrin, an aphid antifeedant diterpene from Plectranthus barbatus. Chem. Lett. 1984, 9, 1513-1516.

15. Yamashita, A.; Takashita, T.; Ishihara, T. Antiobesity agents and food, beverage, and medical compositions containing bergenin and forskolin and/or astilbin. Japanese Patent 2004, 2004091464A.

16. Godard, M.P.; Johnson, B.A.; Richmond, S.R. Body composition and hormonal adaptations associated with forskolin consumption in overweight and obese men. Obesity Res. 2005, 13, 1335-1343.

17. Bonte, F.; Meybeck, A.; Marechal, C. Composition based on hydrated lipidic lamellar phases or on liposomes containing at least one derivative of labdane, or a plant extract containing it; cosmetic or pharmaceutical, particularly dermatological composition containing it. US Patent 1999, 5891464.

Bull. Chem. Soc. Ethiop. 2018, 32(3) 
18. Liu, J.; Zhang, J.; Chen, Z.; Xu, Y.L.; Jin, Q.D. Chinese medicine composition for treating asthma and cough and its preparation. Chinese Patent 2006, 1872146A.

19. Adachi, H.; Ehata, S.; Hayashi, T. Antiaging cosmetics containing Coleus forskohlii root extracts and antioxidants. Japanese Patent 1996, 08176005A.

20. Kawakami, T. Anti-allergy compositions containing Coleus forskohlii root extract and cinnamon extract. Japanese Patent 2003, 2003252786A.

21. Camara, C.C.; Nascimento, N.R.; Macedo-Filho, C.L.; Almeida, F.B.; Fonteles, M.C. Antispasmodic effect of the essential oil of Plectranthus barbatus and some major constituents on the guinea-pig ileum. Planta Med. 2003, 69, 1080-1085.

22. Fischman, L.A.; Skorupa, L.A.; Souccar, C.; Lapa, A.J. The water extract of Coleus barbatus Benth decreases gastric secretion in rats. Memo. Inst. Oswaldo Cruz. 1991, 86, 141-143.

23. Yadava, J.N.S.; Gupta, S.; Ahmad, I.; Varma, N.; Tandon, J.S. Neutralization of enterotoxins of Escherichia coli by coleonol (forskolin) in rabbit and guinea pig ileal loop models. Indian J. Anim. Sci. 1995, 65, 1177-1181

24. Almeida, F.C.; Lemonica, I.P. The toxic effects of Coleus barbatus B on the different periods of pregnancy in rats. $J$. Ethnopharmacol. 2000, 73, 53-60.

25. Majeed, M.; Prakash, S. Composition and methods containing an antimicrobial essential oil extended from Coleus forskohlii. US Patent 2003, 6607712B2.

26. Alasbahi, R.H.; Melzig, M.F. Plectranthus barbatus: a review of phytochemistry, ethnobotanical uses and pharmacology-part 2. Planta Med. 2010, 76, 753-765.

27. Abdel-Mogib, M.; Albar, A.A.; Batterjee, S.M. Chemistry of the genus Plectranthus. Mol. 2002, 7, 271-301.

28. Kerntopf, M.R.; Albuquerque, R.L.; Machado, M.I.L.; Matos, F.J.A.; Craveiro, A.A. Essential oils from leaves, stems, and roots of Plectranthus barbatus Andr. (Labiatae) grown in Brazil. J. Essent. Oil Res. 2002, 14, 101-102.

29. Sousa, M.P.; Matos, M.E.O.; Matos, F.J.A.; Machodos, M.I.L; Craveiro, A.A. Constituintes quimicos ativose propriedades biologicas de plantas medicinais brasileiras. Ed UFC Fortalez 2004, 330-335.

30. Zelnik, R.; Lavie, D.; Levy, E.C.; Wang, A.H.J.; Paul, I.C. Barbatusin and cyclobutatusin, two novel diterpenoids from Coleus barbatus Bentham. Tetrahedron 1977, 33, 1457-1467.

31. Le Roux, A.M.; Wium, C.A.; Joubert, J.R.; Van Jaarsveld, P.P. Evaluation of a highperformance thin-layer chromatographic technique for the determination of salbutamol serum levels in clinical trials. J. Chromatogr. 1992, 581, 306-309.

32. Hussain, M.S.; Sheeba, F.; Ali, M. Validation of the method for the simultaneous estimation of bioactive marker gallic acid and quercetin in Abutilon indicum by HPTLC. Asian Pac. J. Trop. Dis. 2012, 2, S76-S83.

33. Chao, K.P.; Hua, F.F.; Hsu, H.Y.; Su, Y.C.; Chang, S.T. Anti-inflammatory activity of sugiol, a diterpene isolated from Calocedrus formosana Bark. Planta Med. 2005, 71, 300305.

34. Jung, S.N.; Shin, D.S.; Kim, H.N.; Jeon, Y.J.; Yun, J.; Lee, Y.J.; Kang, J.S.; Han, D.C.; Kwon, B.M. Sugiol inhibits STAT3 activity via regulation of transketolase and ROSmediated ERK activation in DU145 prostate carcinoma cells. Biochem. Pharmacol. 2015, 97, 38-50.

35. Politi, M.; Braca, A.; De Tommasi, N.; Morelli, I.; Manunta, A.; Battinelli, L.; Mazzanti, G. Antimicrobial diterpenes from the seeds of Cephalotaxus harringtonia var. drupacea. Planta Med. 2003, 69, 468-470.

36. Tezuka, Y.; Kasimu, R.; Basnet, P.; Namba, T.; Kadota, S. Aldose reductase inhibitory constituents from the root of Salvia miltiorrhiza Bunge. Chem. Pharm. Bull. 1997, 45, 6972. 
37. Iwamoto, M.; Minami, T.; Tokuda, H.; Tanaka, R. Potential antitumor promoting diterpenoids from the stem bark of Thuja standishii. Planta Med. 2003, 69, 69-72.

38. Kuo, Y.H.; Chen, C.H.; Huang, S.L. New diterpenes from the heartwood of Chamaecypariso btusa var. formosana. J. Nat. Prod. 1998, 61, 829-831.

39. International Conference on Harmonization (ICH) of Technical Requirements for Registration of Pharmaceuticals for Human use, Harmonised Triplicate Guideline on Validation of Analytical Procedures: Methodology, Recommended for Adoption at Step 4 of the ICH process on November 1996 by the ICH Steering Committee, IFPMA, Geneva.

40. Haq, N.; Siddiqui, N.A.; Alam, P.; Shakeel, F.; Alaanaz, F.K.; Alsarra, I.A. Estimation of sodium lauryl sulfate concentration in marketed formulations by stability indicating 'green' planar chromatographic method. Lat. Am. J. Sci. 2018, 45, 1531-1542.

41. Amina, M.; Alam, P.; Parvez, M.K.; Al-Musayeib, N.M.; Al-Hwaity, S.A.; Al-Rashidi, N.S.; Al-Dosari, M.S. Isolation and validated HPTLC analysis of four cytotoxic compounds, including a new sesquiterpene from aerial parts of Plectranthus cylindraceus. Nat. Prod. Res. 2018, 32, 804-809.

42. Siddiqui, N.A.; Al-Yousef, H.M.; Alhowiriny, T.A.; Alam, P.; Hassan, W.H.B.; Amina, M.; Hussain, A.; Abdelaziz, S.; Abdallah, R.H. Concurrent analysis of bioactive triterpenes oleanolic acid and $\beta$-amyrin in antioxidant active fractions of Hibiscus calyphyllus, Hibiscus deflersii and Hibiscus micranthus grown in Saudi Arabia by applying validated HPTLC method. Saudi Pharm. J. 2018, 26, 266-273.

43. Alam, P.; Al-Rehaily, A.J.; Siddiqui, N.A.; Al-Sheddi, E.; Shakeel, F. A stabilityindicating assay of biomarker bergenin in the aerial parts of Flueggea virosa by a validated high-performance thin-layer chromatographic-densitometric method. J. Plan. Chromatogr. 2015, 28, 54-60.

44. Alam, P.; Basudan, O.A.; Siddiqui, N.A.; Al-Rehaily, A.; Alqasoumi, S.; Abdel-Kader, M.; Donia, A.; Alam, P. Development of a densitometric high-performance thin-layer chromatographic method for the quantitative analysis of biomarker lupeol in the leaves of different species of genus Ficus. J. Plan. Chromatogr. 2015, 28, 30-35.

45. Shukla, M.; Jaiswal, S.; Sharma, A.; Srivastava, P.K.; Arya, A.; Dwivedi, A.K.; Lal, J. A combination of complexation and self-nanoemulsifying drug delivery system for enhancing oral bioavailability and anticancer efficacy of curcumin. Drug Develop. Ind. Pharm. 2017, 43, 847-861.

46. Alshahrani, S.M.; Alshetaili, A.S.; Alalaiwe, A.; Alsulays, B.B.; Anwer, M.K.; Al-Shdefat, R.; Imam, F.; Shakeel, F. Anticancer efficacy of self-nanoemulsifying drug delivery system of sunitinib malate. AAPS PharmSciTech. 2018, 19, 123-133.

47. Alam, P.; Siddiqui, N.A.; Basudan, O.A.; Al-Rehaily, A.; Alqasoumi, S.I.; Alam, P.; AbdelKader, M.S.; Donia, A.E.M.; Shakeel, F. Comparative profiling of biomarker psoralen in antioxidant active extracts of different species of genus Ficus by validated HPTLC method. Afr. J. Trad. Compl. Alt. Med. 2015, 12, 57-67.

48. Alajmi, M.F.; Alam, P.; Siddiqui, N.A.; Basudan, O.A.; Hussain, A. Quantitative analysis of biomarker rutin in different species of genus Ficus by validated NP and RP-HPTLC methods. Pak. J. Pharm. Sci. 2015, 28, S2213-S2220.

49. Alam, P.; Siddiqui, N.; Al-Rehaily, A.; AlAjmi, M.; Basudan, O.; Khan, T. Stabilityindicating densitometric high-performance thin-layer chromatographic method for the quantitative analysis of biomarker naringin in the leaves and stems of Rumex vesicarius L. $J$. Plan. Chromatogr. 2014, 27, 204-209. 